\title{
Pembangunan Modal Insan Melalui Kurikulum Pusat Asuhan Tunas Islam Malaysia
}

\section{Human Development through Islamic Preschool Curriculum at Pusat Asuhan Tunas Islam (PASTI)}

\author{
Nor Raudah Hj Siren \\ Department of Da 'wah and Human Development, Academy of Islamic Studies, \\ University of Malaya, 50603 Kuala Lumpur, Malaysia. raudah68@um.edu.my \\ Salmee Suhaina Yusoff \\ Centre for Fundamental Studies, Management and Science University, \\ University Drive, Off Persiaran Olahraga, Section 13, 40100 Shah Alam, \\ Selangor, Malaysia. salmee_suhaina @msu.edu.my \\ DOI: https://doi.org/10.22452/usuluddin.vol48no1.4
}

\begin{abstract}
Islamic education, introduced for childhood, is very important in shaping the identity of muslim in young children. Education for young children in this life requires specific models and methods in order to produce human capital capable of high godly devotion to Allah Almighty. Therefore, this article has analyzed the preschool curriculum implemented at the Pusat Asuhan Tunas Islam (PASTI) to see how PASTI develops the curriculum and implements the curriculum in an effort to foster the virtues of children. The analysis found that the PASTI curriculum is still within the framework of National curriculum development because it has components of cognitive development, language and communication development, psychomotor development and socioemotional development. However PASTI has implemented the process of teaching and learning in an interdisciplinary manner according to its vision and mission of education.
\end{abstract}

Keywords: Islamic preschool, Islamic preschool curriculum, Islamic kindergarten, early childhood education

\begin{abstract}
Abstrak
Pendidikan Islam yang diperkenalkan sejak awal usia kanak-kanak amat penting dalam pembentukan pengenalan tentang Islam dalam diri kanakkanak yang masih putih hatinya. Pendidikan terhadap kanak-kanak yang masih mentah dalam soal kehidupan ini memerlukan model dan metode yang tertentu agar mampu menghasilkan modal insan yang mampu memiliki sifat takwa yang tinggi kepada Allah SWT. Lantaran itu, artikel ini telah menganalisis kurikulum prasekolah yang dilaksanakan di Pusat Asuhan Tunas Islam (PASTI) bagi melihat bagaimana PASTI membangun kurikulum dan melaksanakan kurikulum tersebut dalam usaha melahirkan sifat ta'abbud dalam diri kanak-kanak. Analisis
\end{abstract}


mendapati, kurikulum PASTI masih berada dalam rangka pembangunan kurikulum Kebangsaan kerana memiliki komponen pembangunan kognitif, pembangunan bahasa dan komunikasi, pembangunan psikomotor dan pembangunan sosioemosi. Namun PASTI telah melaksanakan proses pengajaran dan pembelajaran secara intergrasi berdasarkan modul tersendiri sebagaimana dalam visi dan misi pendidikannya.

Kata kunci: prasekolah Islam, kurikulum prasekolah Islam, tadika Islam, pendidikan awal kanak-kanak

\section{Pendahuluan}

Penekanan pendidikan awal kanak-kanak adalah sangat penting untuk menghasilkan generasi Islam yang berkualiti dan memahami Islam secara holistik. Islam telah menekankan beberapa pendekatan ataupun metodologi yang sesuai kepada kanak-kanak untuk membentuk mereka menjadi generasi pelapis yang mempunyai sifat taqwa yang tinggi kepada Allah.

Kurikulum merupakan asas yang penting dalam pendidikan formal di Malaysia. Umumnya kurikulum merangkumi segala kegiatan sekolah yang formal iaitu merupakan aktiviti-aktiviti dan pengalaman-pengalaman yang sengaja dirancang oleh pihak sekolah untuk mencapai objektif sama ada dalam bilik darjah atau di luar bilik darjah. ${ }^{1}$ Kurikulum formal ialah rancangan aktiviti pembelajaran yang dijalankan supaya matlamat atau objektif pendidikan dan sekolah tercapai. Ia merupakan satu set dokumen untuk dilaksanakan. Ia mengandungi hal sebenar yang berlaku di bilik darjah berkaitan dengan bahan pengajaran yang telah disediakan oleh guru dan telah dinilai oleh pihak pembentuk kurikulum. Setiap sekolah ada kurikulum terancang iaitu satu set objektif yang berstruktur dengan kandungan dan pengalaman belajar serta hasil yang dijangkakan. ${ }^{2}$

Pembentukan model kurikulum prasekolah Islam perlu kepada aspek yang mempengaruhi perkembangan dalaman (roh, pemikiran dan perasaan) kanak-kanak melalui penyuburan dan

1 Ishak Ramly Inilah Kurikulum Sekolah (Kuala Lumpur: PTS Profesional, 2005), 7.

2 Ilmu dan Aplikasi Pendidikan Bagian I: Ilmu Pendidikan Teoreti (Jakarta: PT Imperial Bhakti Utama, 2007), 98. 
pengukuhan iman di samping perkembangan fizikal. ${ }^{3}$ Pelaksanaan program pendidikan prasekolah Islam juga perlu memfokus kepada latihan membentuk akhlak mulia dan terpuji serta menghindari diri dari sifat yang tidak baik ${ }^{4}$ bagi mempastikan kanak-kanak dilatih sedari awal perkembangannya. Bagi mencapai hasrat tersebut maka, kurikulum prasekolah Islam perlu mengikuti matlamat dan objektif sebagaimana yang digariskan oleh Kementerian Pendidikan Negara iaitu menyuburkan potensi kanak-kanak dalam semua aspek perkembangan, emnguasai kemahiran asas dan memupuk sikap positif sebagai persediaan untuk memasuki sekolah rendah. Lantaran itu, pendidikan prasekolah perlu membolehkan kanak-kanak memiliki sifat peribadi, perwatakan dan konsep kendiri yang positif, memiliki perkembangan kemahiran berbahasa untuk berkomunikasi, memiliki kemahiran kognitif, kematangan emosi, kemahiran sosial dan mengamalkan ajaran Islam dengan baik dalam kehidupan. ${ }^{5}$

Pendidikan pra-sekolah Islam merupakan satu usaha bersepadu dan berterusan ke arah melahirkan generasi Islam yang baik dari aspek sahsiah, keilmuan dan amalan-amalan yang bertunjangkan Islam, Iman dan Ihsan. Hal ini juga perlu dilaksanakan dengan mengambil kira potensi dan bakat yang sedia ada dalam kalangan kanak-kanak. Oleh itu, kurikulum prasekolah Islam dilaksanakan dengan mengembangkan kemahiran kognitif, psikomotor atau fizikal, bahasa dan komunikasi, sosioemosi dan sosial selain memupuk kepelbagaian bakat kreativiti dan estetika dalam diri kanak-kanak. ${ }^{6}$ Menurut Khairiah (2011), usaha-usaha ini dilaksanakan menerusi pembentukan peribadi dengan mempersiapkan diri kanak-kanak agar menjadi warga yang mengamalkan cara hidup Islam yang diredai oleh Allah SWT di dunia dan di akhirat. ${ }^{7}$

3 Saedah Siraj, Pendidikan Anak-anak (Selangor: Alam Pintar, 2003), 9.

4 Kamarul Azmi Jasmi dan Ab Halim Tamuri, Pendidikan Islam Kaedah Pengajaran dan Pembelajaran (Johor: Universiti Teknologi Malaysia, 2007), 1.

5 Kementerian Pelajaran Malaysia, Huraian Kurikulum Prasekolah Kebangsaan (Kuala Lumpur: Kementerian Pendidikan Malaysia, 2008), 2-3.

6 Kementerian Pelajaran Malaysia, Huraian Kurikulum Prasekolah Kebangsaan, 13.

7 Hjh Khairiah Mohd (Bahagian Kurikulum Jabatan PASTI Malaysia Kurikulum 4 tahun (K4T)), dalam temubual dengan pengkaji, 18 Mei 2011. 


\section{Model Kurikulum Pusat Asuhan Tunas Islam Malaysia}

Pusat Asuhan Tunas Islam (PASTI) merupakan sebuah institusi pendidikan awal kanak-kanak yang diurus oleh Dewan Pemuda PAS. Ia telah ditubuhkan sebagai langkah pelaksanaan usahausaha dakwah melalui sistem pendidikan Islam. Sebuah unit yang dinamakan Jabatan Pendidikan Prasekolah Dewan Pemuda PAS Pusat telah ditubuhkan pada 6 Mei 1988 dengan diketuai oleh Ustaz Abu Bakar Abdullah, dan dibantu oleh Cikgu Noh Ahmad dan Ishak Ismail. Dewan Pemuda PAS Pusat pada tarikh tersebut juga telah bersetuju menerima PASTI sebagai nama rasmi semua institusi pendidikan presekolah milik PAS di seluruh negara. ${ }^{8}$

Semenjak itu, PASTI dilaksanakan secara rasmi dengan membawa Pelan Strategik mereka iaitu melaksanakan struktur pendidikan untuk kanak-kanak dari berusia 4 tahun hingga berusia 12 tahun, menginstitusikan pendidikan prasekolah kurikulum seawal 4 tahun (K4T), mewujudkan kesinambungan pendidikan prasekolah PASTI ke peringkat sekolah rendah dengan menekankan kelas Fardh Ain dan Fardu Kifayah (KAFFAH), menyediakan sistem penilaian berpusat, meningkatkan enrolmen pelajar, memberi penekanan kepada konsep pembelajaran sepanjang hayat khususnya di kalangan ibu bapa dan komuniti dan melahirkan tenaga pelapis PAS yang lebih berkualiti melalui proses pendidikan dan latihan secara formal. Penstrukturan semula sistem pendidikan prasekolah Islam juga dilakukan bagi meningkatkan keyakinan massa terhadap kemampuan Dewan Pemuda PAS khasnya dan PAS amnya dalam menjana kecemerlangan ilmu dan membina generasi Islam yang lebih berwibawa. $^{9}$

Oleh itu, satu sistem kurikulum telah dibangunkan untuk kelas 4 tahun (K4T), 5 tahun (K5T) dan 6 tahun (K6T) yang

8 Azrin Ab Majid, "Membangun Pendidikan Prasekolah Islam di Malaysia: Pengalaman PASTI dalam Pendidikan Islam Malaysia: Membangun Gagasan Baru (Ed. ke-2, Selangor: Jawatankuasa Tetap Pendidikan, Pendidikan Tinggi dan Pembangunan Modal Insan, Kerajaan Negeri Selangor Darul Ehsan, 2011), $145-147$.

9 Azrin Ab Majid, "Membangun Pendidikan Prasekolah Islam di Malaysia: Pengalaman PASTI dalam Pendidikan Islam Malaysia: Membangun Gagasan Baru, 145-147. 
digerakkan oleh Unit Kurikulum di PASTI Pusat berdasarkan model di bawah:

Rajah 1: Model Kurikulum Pra Sekolah Islam PASTI. ${ }^{10}$

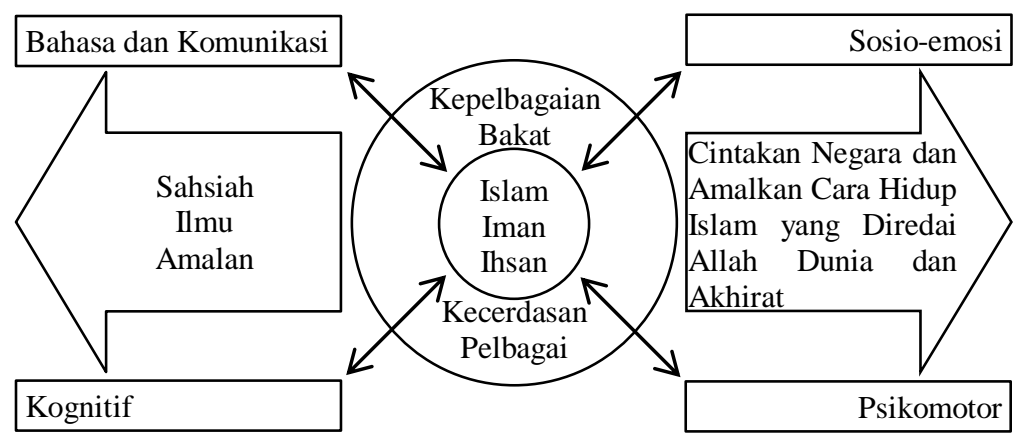

Sumber: PASTI Pusat

Berdasarkan Rajah 1 di atas, bulatan besar menunjukkan diri seseorang kanak-kanak yang mempunyai potensi dan bakat serta kecerdasan pelbagai yang sedia terpupuk dalam diri mereka. Kanak-kanak ini mempunyai dunia kehidupannya yang tersendiri yang ditunjukkan dalam bentuk empat segi sama iaitu kehidupan di rumah mahupun di sekolah yang dilihat dari aspek perkembangan bahasa dan komunikasi, perkembangan sosio emosi, perkembangan kognitif dan perkembangan psikomotor mereka.

Oleh itu, pembentukan kurikulum pendidikan untuk kanakkanak prasekolah perlu dibangunkan berdasarkan dunia dan persekitaran mereka. Pembentukan pendidikan kanak-kanak yang dibentuk oleh PASTI juga menekankan aspek perkembangan kognitif, psikomotor, bahasa dan komunikasi serta sosioemosi kanak-kanak tersebut. Maka dengan itu, aktiviti yang dijalankan turut bersesuaian dengan kehendak perkembangan yang diperlukan dan bersesuaian dengan keperluan mereka.

Pembentukan perkembangan ini dilaksanakan bertunjangkan tiga aspek utama iaitu Islam, Iman dan Ihsan. Tunjang keimanan, keislaman dan ihsan ini ditekankan dalam PASTI bagi melahirkan kanak-kanak yang mantap dari aspek sahsiah, ilmuan dan amalannya serta mampu menjadi warga yang cintakan negara dan

${ }^{10}$ Draf Kurikulum PASTI tahap dua (6 tahun), 3. 
mengamalkan cara hidup Islam yang diredai Allah SWT di dunia dan di akhirat. Oleh itu, kanak-kanak mampu dilahirkan sebagai anak yang soleh lagi pintar.

Berdasarkan model kurikulum prasekolah Islam di atas, PASTI telah membangun tiga (3) kurikulum iaitu kurikulum 4 tahun (K4T), Kurikulum 5 tahun (K5T) dan kurikulum 6 tahun $(\mathrm{K} 6 \mathrm{~T})^{11}$. Kelas untuk pelajar berusia 4 tahun menggunakan kurikulum K4T. Ia dilaksanakan dengan mewujudkan pelbagai ruang aktiviti yang berlainan secara terbimbing dan terpandu. Kanak-kanak melakukan aktiviti berdasarkan beberapa kumpulan mengikut ruang yang disediakan seperti sudut matematik, sudut Bahasa Melayu, sudut kognitif dan sebagainya sama ada dilaksanakan secara solitary (persendirian dengan bimbingan) mahupun secara kumpulan. Aktiviti luar darjah juga dilaksanakan secara aktif. Kaedah ini akan menggalakkan kanak-kanak meneroka pembelajaran mereka. ${ }^{12}$

Kurikulum 5 tahun (K5T) pula dibangunkan berdasarkan kurikulum asas prasekolah sebagaimana yang ditetapkan oleh pihak Kementerian Pendidikan Malaysia iaitu mata pelajaran Bahasa Melayu, Inggeris, Matematik dan Pendidikan Sains Sosial dan Pembangunan Insan. Tetapi PASTI telah menambah mata pelajaran Jawi, Bahasa Arab, Peribadi Muslim dan Komputer sebagai memenuhi matlamat pendidikan PASTI. ${ }^{13}$ Kurikulum 6 tahun (K6T) pula mengandungi kurikulum yang sama dengan kurikulum 5 tahun (K5T). Tetapi aras pembelajarannya berbeza kerana ia lebih bersifat kesinambungan proses perkembangan pembelajaran kanak-kanak yang berada di PASTI sejak di usia 5 tahun. ${ }^{14}$

Sistem pelaksanaan kurikulum K5T dan K6T lebih bersifat aktiviti dalam kelas dan luar bilik darjah. Aktiviti pembelajarannya lebih menekankan komponen kurikulum yang telah diolah oleh PASTI Pusat. Contohnya bagi mata pelajaran Bahasa Melayu, di samping pengajaran mengenal huruf, aktiviti lain melibatkan perkembangan kognitif, psikomotor, sosioemosi,

11 Draf Kurikulum Empat Tahun PASTI Malaysia 2006.

${ }^{12}$ Hjh Khairiah Mohd, temubual, 18 Mei 2011.

13 Draf Kurikulum PASTI 5 tahun.

14 Draf Huraian Sukatan Pelajaran PASTI tahap dua (6 tahun), 2. 
rohani dan perkembangan kreativiti kanak-kanak turut dilakukan. Semasa proses pengajaran tersebut juga, konsep ta'abbud turut dilaksanakan.

\section{Pendekatan Pelaksanaaan Kurikulum PASTI}

Kurikulum PASTI dibangunkan berasaskan kepada lima pendekatan bagi memastikan pelaksanaannnya memenuhi objektif penubuhan PASTI dan hasrat Dewan Pemuda sebagaimana berikut:

i. Pendekatan Pembelajaran Berfikrah dan Bersepadu (PBB) Pendekatan ini dilakukan secara bertema iaitu berasaskan empat unsur utama kejadian alam iaitu tanah, air, api dan angin serta perkaitannya dengan kejadian manusia dan kekuasaan Allah. Tema ini diolah dalam aktiviti harian murid ke arah pendidikan kanak-kanak dengan memenuhi ciri-ciri falsafah pendidikan Negara, falsafah pendidikan Islam dan falsafah pendidikan PASTI. ${ }^{15}$

Pendekatan pengajaran dan pembelajaran bertema adalah salah satu kaedah yang boleh digunakan oleh guru di prasekolah bagi menyusun pengalaman pembelajaran kepada kanak-kanak dan mengintegrasikan pelbagai bidang perkembangan dan memberi pengalaman langsung kepada kanak-kanak. ${ }^{16}$ Pendekatan pembelajaran dan pembelajaran bertema ini dapat membawa faedah kepada guru dan kanak-kanak. Antara faedahnya ialah kanak-kanak dapat mendalami topik, kepelbagaian aktiviti pembelajaran boleh dilakukan, menggalakkan pengembangan ciri kepimpinan dan toleransi dan guru lebih kreatif dalam merancang pengajaran. ${ }^{17}$ Sebagai contoh, jika pada minggu pertama adalah bertemakan buah-buahan, maka aktiviti yang diadakan pada minggu tersebut adalah berkisar buah-buahan seperti mewarna buah-buahan, mengenal buah-buahan dan merasa buah-buahan.

ii. Pendekatan Pembelajaran yang Menekankan Aspek Ta'abbud (Ketaatan Kepada Allah)

15 Hjh Khairiah Mohd, temubual, 18 Mei 2011.

16 Nor Hashimah binti Hashim dan Yahya Che Lah, Panduan Pendidikan Prasekolah (Selangor: PTS Profesional Publishing Sdn Bhd, 2007), 111.

17 Rohani Abdullah et.al., Panduan Kurikulum Prasekolah (Kuala Lumpur: PTS Profesional Pendidikan, 2005 ), 38. 
Pendekatan yang menekankan aspek taabud ini dimasukkan dalam kesemua aktiviti pengajaran dan pembelajaran PASTI. Menurut Puan Khairiah:

"Konsep ta'abbud akan dimasukkan dan diserapkan dalam semua perkembangan iaitu perkembangan bahasa dan komunikasi, perkembangan kognitif, perkembangan fizikal, perkembangan emosi."

Sebagai contoh dalam kemahiran mendengar, konsep ta'abbud ini diserapkan dan direalisasikan dengan cara memasukkan bunyi alam sekitar seperti bunyi petir, bunyi guruh dan bunyi air terjun. Kanak-kanak akan didedahkan tentang siapa yang mencipta kejadian alam dan menerapkan konsep mesti patuh kepada Allah yang hebat menciptakan. Contoh yang lain pula, ketika lukisan yang berbentuk bintang diwarnakan, para pelajar diterapkan tentang Allah tuhan yang berkuasa mencipta alam yang indah ini dan kita sebagai hamba perlu bersyukur dan melakukan segala suruhan dan larangan Allah. Menurut Puan Khairiah:

"Pada peringkat awal kita nak bina K4T ni kita jumpa Dr.

Sufian sebagai penasihat kami, maka dia mencadangkan supaya tema-tema yang kita nak bawa ni berunsurkan tema yang bersumberkan kejadian alam. Maknanya hubungan makhluk dengan pencipta dan kita tak boleh lari daripada hubungan itulah." 19

iii. Pendekatan Pembelajaran Eksplorasi Berpandu dan Terbimbing

Pendekatan ini menekankan aktiviti kendiri (hands-on) murid dan menyediakan pembelajaran yang menggembirakan (belajar sambil bermain). Pihak PASTI telah menyediakan ruang-ruang yang sesuai untuk digunakan oleh para pelajar serta dibimbing oleh para guru seperti sudut bacaan, sudut binaan, sudut matematik, sudut bahasa, sudut melukis, sudut kolaj, sudut mainan pasir dan sudut mainan air. Kesemua ruang ini akan membantu para pelajar dalam perkembangan fizikal dan mental kanak-kanak dan memberi kegembiraan kepada mereka semasa belajar.

Pendekatan yang dilakukan secara eksplorasi ini, muridmurid akan melalui pengalaman secara langsung dengan

18 Hjh Khairiah Mohd, temubual, 18 Mei 2011.

19 Hjh Khairiah Mohd, temubual, 18 Mei 2011. 
melakukan aktiviti pembelajaran sendiri dengan bimbingan guru sama ada terhasil daripada pengalaman ketika bermain permainan ataupun dengan cara berimaginasi. ${ }^{20}$ Kanak-kanak akan membina pengetahuan secara aktif dan berupaya membina kefahaman berdasarkan apa yang dipelajari. ${ }^{21}$ Sebagai contoh, aktiviti seperti bermain pasir dan bermain air mampu memberi pembelajaran langsung dan mampu memberi pembelajaran yang menggembirakan mereka.

Penekanan kepada pembelajaran yang mengembirakan ataupun bermain sambil belajar dapat membantu kanak-kanak memahami aktiviti di sekitar mereka, membentuk personaliti, meningkatkan keyakinan diri, meningkatkan kebolehan fizikal, mengenal persekitaran fizikal, meluahkan segala perasaan dan kretiviti menyelesaikan masalah. ${ }^{22}$

iv. Pendekatan Penilaian Terhadap Perkembangan Tingkah Laku dan Pembelajaran Secara Individu ${ }^{23}$

Setiap pelajar akan dikenal pasti tahap perkembangan masingmasing dan akan dilengkapkan di dalam borang yang disediakan. Antara tahap perkembangan yang dinilai ialah fizikal, perkembangan penulisan, perkembangan sosial, perkembangan kognitif, perkembangan bahasa, perkembangan emosi, perkembangan bacaan dan hafazan. ${ }^{24}$

\section{v. Pendekatan Pendidikan Sepanjang Hayat ${ }^{25}$}

Konsep pembelajaran sepanjang hayat adalah untuk mengalakkan perkembangan ilmu pengetahuan dan sebagai memperolehi dan mengemaskini pengetahuan pada usia prasekolah sehinggalah ke akhir kehidupan. ${ }^{26}$ Dalam hal ini, PASTI telah meneruskan legasi pendidikan Islam dengan membentuk kurikulum sekolah rendah

${ }^{20}$ Hjh Khairiah Mohd, temubual, 18 Mei 2011.

21 Chai Jia Yun, Kesan Penggunaan Kaedah "Hands-On" dalam Proses Pembelajaran Sains Tahun 3 (Koleksi Artikel Penyelidikan Tindakan PISMP SN amb. Januari 2009, Seminar Penyelidikan Tindakan IPG KBL Tahun 2012, 165-179.

22 Mohd Sharani Ahmad, Psikologi Kanak-kanak (Selangor: PTS Profesional Publishing Sdn. Bhd., 2006), 171.

${ }^{23}$ Draf Kurikulum Empat Tahun PASTI Malaysia 2006.

${ }^{24}$ Hjh Khairiah Mohd, temubual, 18 Mei 2011.

25 Draf Kurikulum Empat Tahun PASTI Malaysia 2006.

${ }^{26}$ Irma Indayu Omar dan Yushiana Mansor, Panduan Mencari Maklumat (Selangor: PTS Profesional, 2005), 17. 
yang mengutamakan kelas Fardh Ain dan Fardu Kifayah (KAFFAH) dan PAS sendiri telah menubuhkan beberapa sekolah agama peringkat menengah dan Institusi Pengajian Tinggi Swasta di peringkat Diploma.

\section{Objektif Kurikulum PASTI}

PASTI telah menggariskan beberapa objektif dalam kurikulumnya untuk mencapai misi dan visi yang telah ditetapkan. Antara Objektif Kurikulum PASTI ${ }^{27}$ ialah:

1. Membolehkan murid-murid mengesakan dan mengagungkan Allah SWT melalui kesemua aktiviti pembelajaran yang dilakukan. Guru-guru berperanan besar dalam memastikan proses pengajaran dan pembelajaran sentiasa tidak terpisah dengan mendekatkan diri kanak-kanak agar sentiasa mengingati dan mengesakan Allah SWT.

2. Mengaitkan seluruh aspek kehidupan dengan Pencipta. Lantaran itu kurikulum PASTI menerapkan empat tema utama iaitu tanah, air, api dan angin serta perkaitannya dengan kejadian manusia dan kekuasaan Allah.

3. Menggalakkan para pelajar mengamalkan nilai-nilai Islam dalam kehidupan. Murid-murid didedahkan dengan keindahan Islam dalam mewarnai kehidupan seharian melalui proses pengajaran dan pembelajaran PASTI. Contoh guru-guru menerapkan sifat sabar dan tolak ansur dalam setiap aktiviti murid-murid melalui pesanan yang disampaikan.

4. Memupuk sifat menghargai, mencintai dan mengamalkan ilmu yang dipelajari. Murid-murid didedahkan dengan sifat-sifat menghargai ilmu yang dipelajari semasa di dalam kelas dan seterusnya mengamalkannya dalam kehidupan seharian mereka.

5. Memperkenalkan asas bacaan al-Quran. Sebelum memulakan pembelajaran pada waktu pagi, para pelajar akan membaca surah-surah pendek secara beramai-ramai dan dipandu oleh guru masing-masing. Antara bacaan awal yang ditekankan oleh PASTI ialah surah-surah pendek seperti surah al-Fatihah, surah al-Nas dan surah Al-falaq. ${ }^{28}$

27 Draf Kurikulum Empat Tahun PASTI Malaysia 2006.
28 Hjh Khairiah Mohd, temubual, 18 Mei 2011. 
6. Menganjurkan dan menerapkan cara bergaul dan berinteraksi dalam kerangka yang dianjurkan dalam Islam. Semua murid dianjurkan mencintai diri, keluarga, masyarakat, agama dan tanah air di samping menghargai jasa serta pengorbanan ibu bapa, guru dan pemimpin negara. Semasa aktiviti pembelajaran berlaku, guru-guru akan menggalakkan sikap kerjasama dan berjemaah dalam aktiviti kelas serta menanamkan semangat gotong-royong dan sukarela. ${ }^{29}$

7. Meningkatkan keyakinan dan kebolehan diri. PASTI juga menekankan aspek emosi kanak-kanak dan mengoptimumkan kecekapan pelbagai deria dalam menyelesaikan masalah dan mencetuskan idea-idea baru semasa proses pembelajaran berlaku. ${ }^{30}$ Aktiviti bercerita, menjawab soalan, membaca doa dan sebagainya akan menggalakkan murid-murid berkeyakinan untuk berhadapan dengan orang ramai dan berani menyuarakan pendapat.

8. Mengasah bakat, minat dan kecenderungan murid. Guru-guru sentiasa mencabar daya kreativiti murid dan menggunakan segala keupayaan yang ada pada diri murid termasuk kemahiran berbahasa untuk menyatakan idea dan keinginan seterusnya mampu menggunakan bahasa Melayu dengan baik untuk berkomunikasi. $^{31}$

\section{Pembangunan Modal Insan Melalui Kurikulum Prasekolah Islam}

Berdasarkan analisis kandungan dalam kurikulum Pendidikan Prasekolah Kebangsaan dan kurikulum PASTI serta penjelasan beberapa sarjana berkaitan dengan kurikulum prasekolah Islam, dapatlah disimpulkan bahawa, pelaksanaan kurikulum prasekolah Islam perlu memenuhi komponen-komponen sebagaimana Rajah 2 bagi memenuhi keperluan pembangunan modal insan.

Pembangunan modal insan ialah proses pengilmuan dan pendidikan insan secara menyeluruh meliputi aspek akal, emosi, fizikal, sosial dan kerohaniannya. Manusia adalah insan yang sempurna sifatnya kerana memiliki akal dan potensi diri untuk

${ }^{29}$ Hjh Khairiah Mohd, temubual, 18 Mei 2011.

${ }^{30}$ Hjh Khairiah Mohd, temubual, 18 Mei 2011.

31 Hjh Khairiah Mohd, temubual, 18 Mei 2011. 
menguasai ilmu bagi tujuan memakmurkan muka bumi dan menjauhkan kerosakan. Pembangunan modal insan meletakkan ilmu sebagai ciri utama yang perlu ditekan dalam melaksana dan merealisasi sistem pendidikan selaras dengan agama Islam yang meletakkan ilmu di tempat yang paling tinggi darjatnya dan sebagai bekal kehidupan manusia di dunia dan akhirat.

Rajah 2: Model Pembangunan Modal Insan Prasekolah Islam

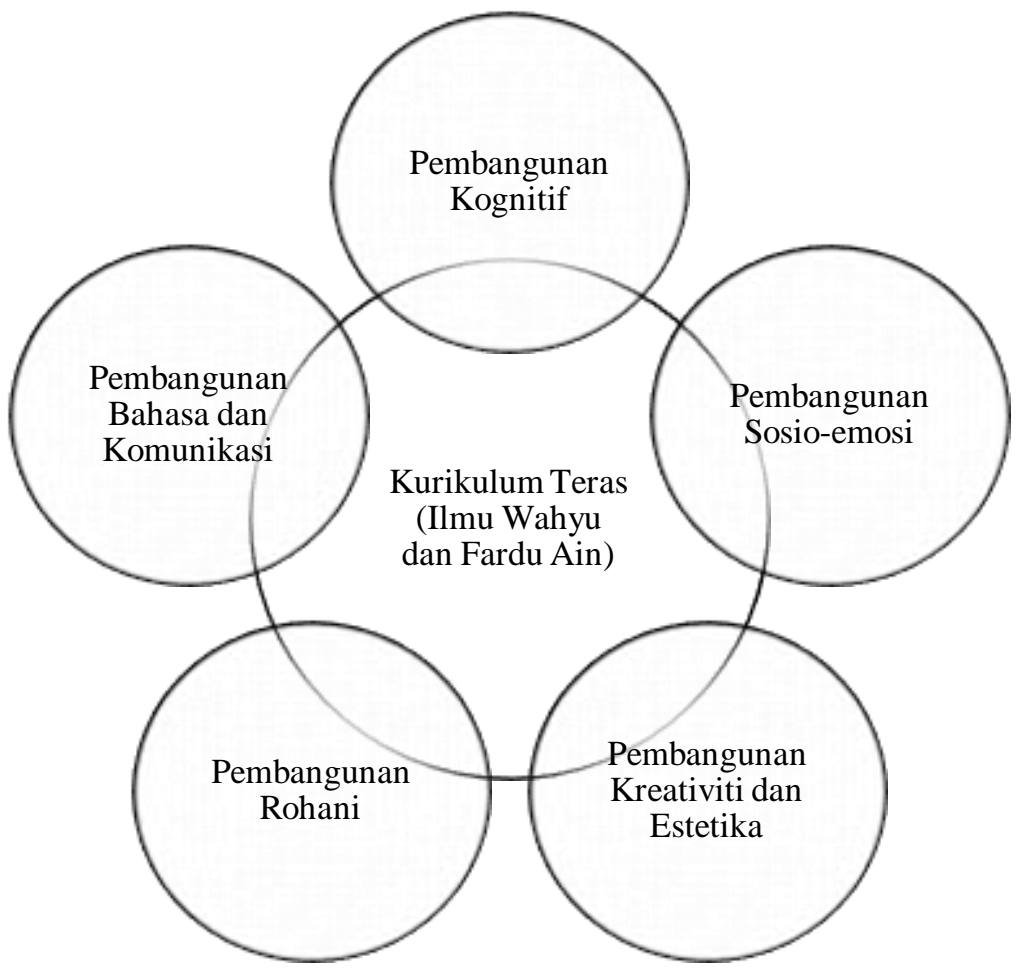

Berdasarkan analisis terhadap kandungan dan pelaksanaan komponen kurikulum PASTI sebenarnya tidak jauh berbeza dengan Kurikulum Pendidikan Prasekolah Kebangsaan malah tidak pernah bertentangan ataupun bercanggah. ${ }^{33}$ Tetapi Kurikulum PASTI menjadi pelengkap kepada kurikulum yang

32 Siti Fatimah Ahmad dan Maimun Aqsha Lubis, "Islam Hadhari dalam Pendidikan Pembangunan Modal Insan di Malaysia: Satu Analisa Epistimologi”, Jurnal Hadhari 7, no. 1 (2015), 1-18.

33 Hjh Khairiah Mohd, temubual, 18 Mei 2011. 
terdapat dalam Kurikulum Prasekolah Kebangsaan dalam usaha melahirkan modal insan negara. Walau bagaimanapun, perbezaannya adalah dari sudut bagaimana pelaksanaan ataupun perkara yang perlu diisi untuk merealisasikan objektif mahupun falsafah sesebuah prasekolah tersebut.

Kurikulum PASTI juga secara asasnya, mempunyai komponen pembangunan modal insan iaitu komponen pembangunan bahasa dan komunikasi dalam bahasa Melayu dan Inggeris yang menekankan aspek kemahiran mendengar, bertutur, membaca dan menulis. Penulisan dan pengenalan huruf-huruf jawi dan bahasa Arab juga tidak ketinggalan ditekankan dalam kurikulum ini. Pembangunan bahasa dan komunikasi bukan sahaja berlangsung di dalam kelas yang dibimbing oleh guru sahaja, malah turut berlangsung semasa para pelajar berkomunikasi sesama mereka ketika bermain di sudut-sudut yang disediakan. ${ }^{34}$

Jadual Bergambar 1: Aktiviti pembangunan bahasa dan komunikasi di PASTI

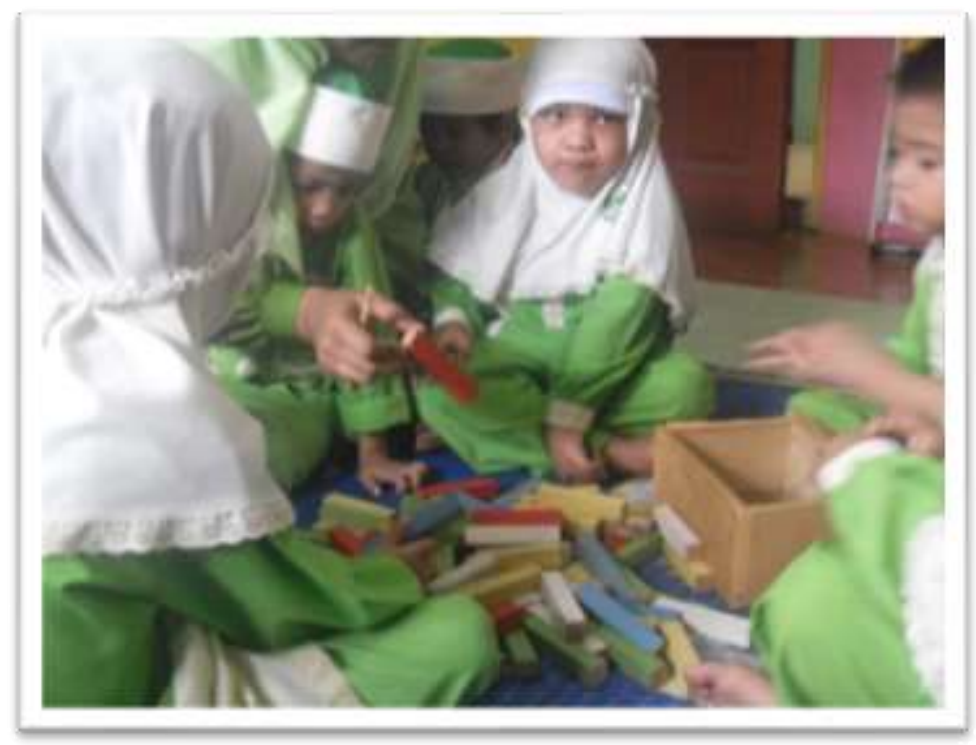

Kanak-kanak saling berkomunikasi dan bekerjasama dalam membina blok-blok kayu.

34 Draf Kurikulum Empat Tahun PASTI Malaysia 2006. 


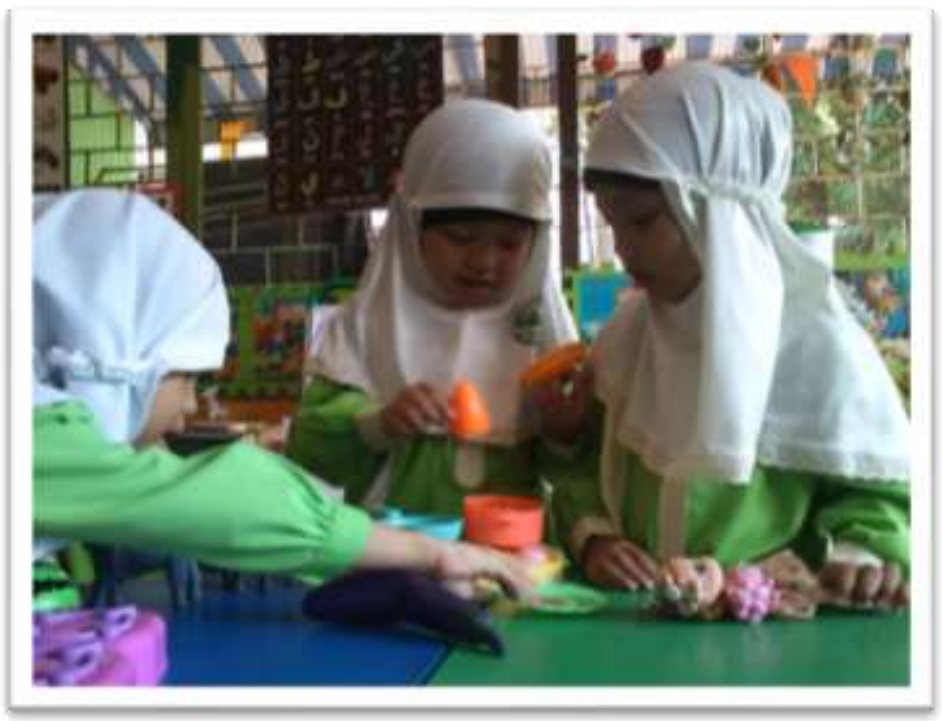

Aktiviti ini membantu mereka membina imaginasi dan memperkembangkan bahasa masing-masing.

Jadual Bergambar 2: Aktiviti pembangunan kognitif di PASTI

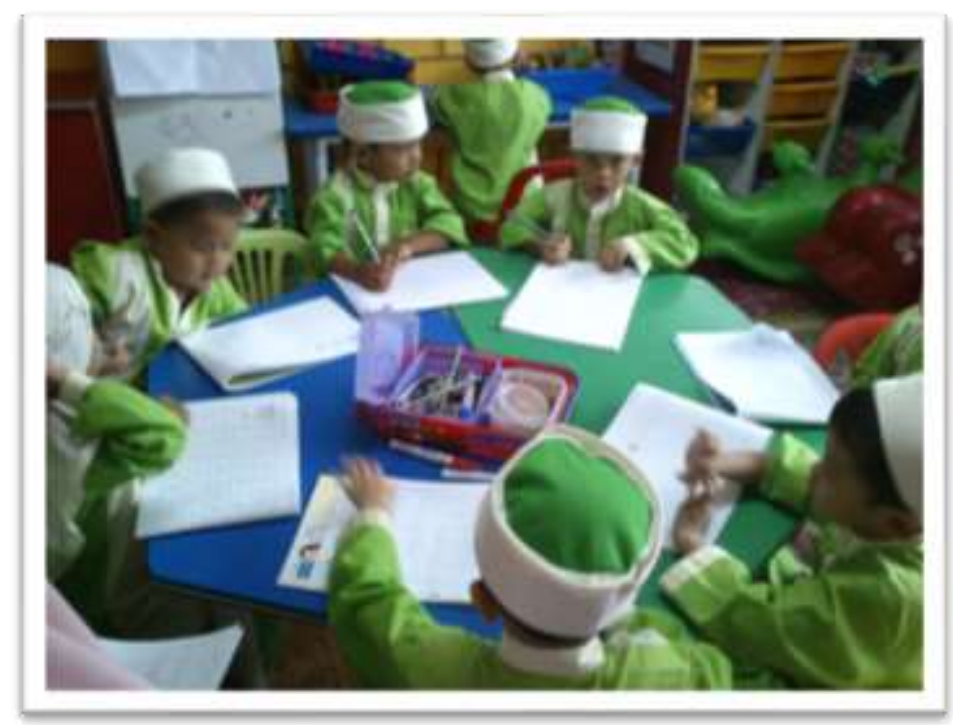

Aktiviti latihan dalam kumpulan membantu mereka mengembangkan kognitif dan menyelesaikan masalah. 


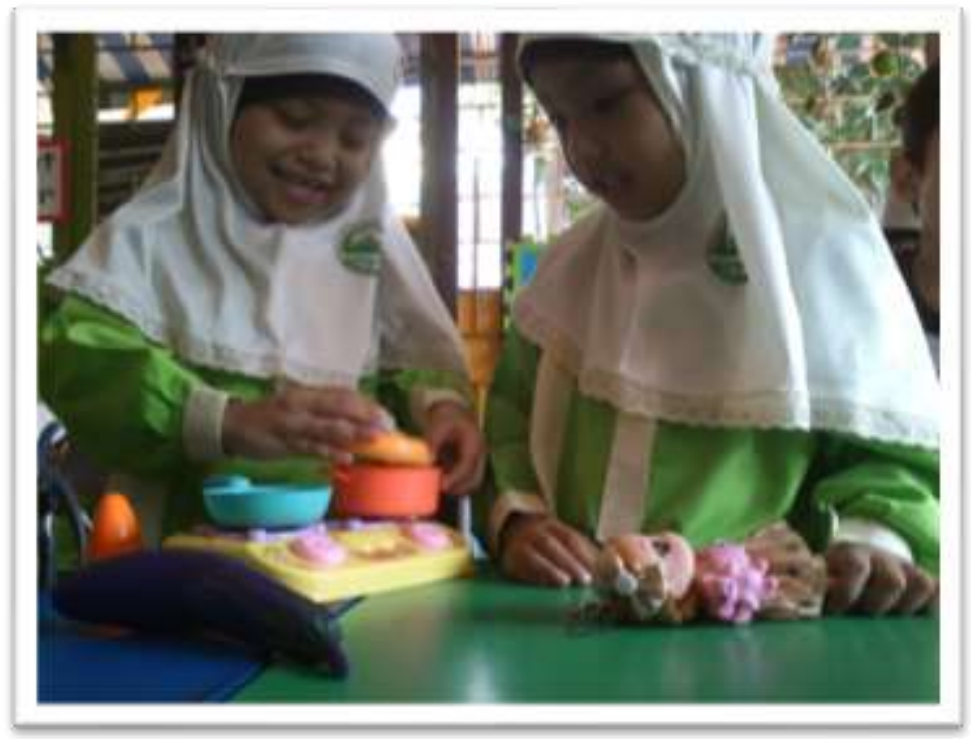

Berimaginasi juga mampu mengembangkan kreativiti dan kognitif.

Komponen pembangunan kognitif pula menekankan aspek pembangunan pemikiran supaya para pelajar berupaya berfikir secara kreatif dan kritis. Kemahiran kognitif merupakan kebolehan individu untuk berfikir, memberi pendapat, memahami, mengingati perkara-perkara yang berlaku di persekitaran mereka yang melibatkan aktiviti-aktiviti seperti ingatan, mengkategori, merancang dan menaakul, menyelesai masalah, mencipta dan berimaginasi. ${ }^{33}$

Seterusnya komponen pembangunan sosio-emosi pula berkait dengan hubungan sosial kanak-kanak dengan individuindividu di sekitar mereka. Kanak-kanak perlu diberi peluang dan sokongan untuk mencuba pengalaman-pengalaman baru. Kanakkanak yang diberi pujian dan galakan akan lebih bersemangat untuk terus melibatkan diri dalam aktiviti kerana mereka merasakan diri lebih dihargai. ${ }^{36}$ Manakala emosi pula merupakan

35 Rohani Abdullah dan Nani Menon, Panduan Kognitif Kanak-kanak Prasekolah, 20-26.

36 Shahabuddin Hashim dan Noor Miza Abdul Rahman, Pendidikan Sosioemosi Kanak-kanak (Selangor: PTS Akademia, 2014), 2. 
perasaan efektif yang dialami oleh setiap individu dalam sesuatu keadaan yang memberi makna kepada dirinya. Ibu bapa dan guru berperanan untuk membangun emosi kanak-kanak dengan memahami dan mengawal emosi mereka. Antara peranan yang harus dimainkan ialah seperti bercakap dan berkomunikasi dengan mereka kerana aktiviti ini boleh menangani perasaan malu, sedih dan marah yang dialami oleh kanak-kanak. ${ }^{37}$

Komponen pembangunan rohani menekankan aspek akidah, akhlak, al-Quran, sirah dan ibadah. Kanak-kanak perlu diasuh dan dibimbing untuk mempraktikkan nilai-nilai Islam dalam kehidupan mereka dengan mengambil kira asas-asas awal perkembangan kanak-kanak bagi melahirkan generasi soleh dan pintar. Menerusi penerapan nilai-nilai murni yang ditanamkan oleh guru-guru PASTI diharap akan terbentuk modal insan yang soleh, berilmu dan berakhlak mulia yang akan menerajui Malaysia suatu hari nanti.

Seterusnya ialah komponen pembangunan kreativiti dan estetika. Unsur-unsur kreativiti dan estetika adalah terdiri daripada elemen asas yang penting dalam menghasilkan sesuatu yang mempunyai unsur kreatif. Dengan alasan itulah, kanak-kanak dibiarkan memilih sudut-sudut yang digemari dan membiarkan mereka membina kreativiti dan imginasi sendiri. ${ }^{38}$

\section{Penutup}

Oleh itu, jelaslah bahawa komponen pembelajaran PASTI yang dilaksanakan bertunjangkan kepada pendidikan wahyu berserta komponen-komponen lain secara tidak langsung telah membantu dalam usaha membangun modal insan negara. Sifat ta'abbud (kehambaan) yang ditekankan dalam sistem kurikulum PASTI menjadi asas penting membangunkan modal insan yang bakal melahirkan masyarakat yang baik dan terpuji akhlaknya. PASTI telah mempunyai satu kurikulum yang sempurna dalam membangun modal insan selaras dengan sistem pendidikan awal kanak-kanak oleh Kementerian Pendidikan Malaysia.

37 Shahabuddin Hashim dan Noor Miza Abdul Rahman, Pendidikan Sosioemosi Kanak-kanak, 39.

38 Draf Kurikulum Empat Tahun PASTI Malaysia 2006. 


\section{Rujukan}

Azrin Ab Majid. "Membangun Pendidikan Prasekolah Islam di Malaysia: Pengalaman PASTI dalam Pendidikan Islam Malaysia: Membangun Gagasan Baru. Ed. ke-2, Selangor: Jawatankuasa Tetap Pendidikan, Pendidikan Tinggi dan Pembangunan Modal Insan, Kerajaan Negeri Selangor Darul Ehsan, 2011.

Chai Jia Yun. Kesan Penggunaan Kaedah "Hands-On" dalam Proses Pembelajaran Sains Tahun 3. Koleksi Artikel Penyelidikan Tindakan PISMP SN amb. Januari 2009, Seminar Penyelidikan Tindakan IPG KBL Tahun 2012.

Ilmu dan Aplikasi Pendidikan Bagian I: Ilmu Pendidikan Teoreti. Jakarta: PT Imperial Bhakti Utama, 2007.

Irma Indayu Omar dan Yushiana Mansor. Panduan Mencari Maklumat. Selangor: PTS Profesional, 2005.

Ishak Ramly. Inilah Kurikulum Sekolah. Kuala Lumpur: PTS Profesional, 2005.

Kamarul Azmi Jasmi dan Ab Halim Tamuri. Pendidikan Islam Kaedah Pengajaran dan Pembelajaran. Johor: Universiti Teknologi Malaysia, 2007.

Kementerian Pelajaran Malaysia. Huraian Kurikulum Prasekolah Kebangsaan. Kuala Lumpur: Kementerian Pendidikan Malaysia, 2008.

Mohd Sharani bin Ahmad. Psikologi Kanak-kanak. Selangor: PTS Profesional Publishing Sdn. Bhd., 2006. Nor Hashimah binti Hashim dan Yahya Che Lah. Panduan Pendidikan Prasekolah. Selangor: PTS Profesional Publishing Sdn Bhd, 2007.

Rohani Abdullah dan Nani Menon. Panduan Kognitif Kanakkanak Prasekolah. Kuala Lumpur: PTS Profesional Pendidikan, 2003.

Saedah Siraj. Pendidikan Anak-anak. Selangor: Alam Pintar Enterprise, 2003.

Shahabuddin Hashim dan Noor Miza Abdul Rahman. Pendidikan Sosioemosi Kanak-kanak. Selangor: PTS Akademia, 2014.

Siti Fatimah Ahmad dan Maimun Aqsha Lubis. "Islam Hadhari dalam Pendidikan Pembangunan Modal Insan di Malaysia: Satu Analisa Epistimologi." Jurnal Hadhari 7, no. 1 (2015), 1-18. 
Raudah dan Salmee, Pembangunan Modal Insan 